\title{
Ekskurzija Društva za antične in humanistične študije: kulturnozgodovinska pot Čez Most po modrost
}

V soboto, 15. maja 2010, se je skupinica članov Društva za antične in humanistične študije in gostov z minibusom podala na Most na Soči na kulturnozgodovinsko pot Čez Most po modrost, ki obiskovalcem predstavlja večtisočletno kulturnozgodovinsko in še posebej arheološko dediščino tega kraja. Na Mostu na Soči je namreč stalo naselje že v srednji ali pozni bronasti dobi; najstarejša lokalna stavba, katere ostanki so se ohranili, izvira iz obdobja 1300-1000 pr. Kr. Največji razcvet Tolminske pa je prišel v starejši železni dobi, katere kultura se imenuje »svetolucijska« prav po Mostu na Soči oziroma njegovem drugem imenu, Sveta Lucija. Imena rimske naselbine na Mostu, ki je doživela svoj višek v 3. in 4. stol. po Kr., sicer žal ne poznamo, ohranjeni pa so denimo impozantni temelji vile, ki je imela celo sudarij (potilnico). Tudi v novejšem času kraj ni izgubil kulturnega pomena, saj je bil dom več slovenskih izobražencev in umetnikov (omenimo lahko hišo pisatelja Ivana Preglja).

Vseh postaj na poti je dvaindvajset, opremljena je $\mathrm{z}$ informacijskimi tablami, razstavnimi nišami z replikami, rekonstrukcijami poslopij ipd., po njej pa nas je $\mathrm{z}$ izrednim poznavalstvom in predanostjo popeljal arheolog Miha Mlinar iz Tolminskega muzeja, njen idejni oče in avtor knjižice Čez Most po modrost. Vreme nam je bilo kljub neugodnim napovedim naklonjeno, zanimivosti, ki smo jih videli na arheološki poti in pozneje še v Tolminskem muzeju ter na Tonovcovem gradu pri Kobaridu, pa so obilno poplačale našo odločitev. Tolminski muzej omogoča obiskovalcu sprehod skozi zgodovino: od originala neandertalčeve piščali prek zakladnih najdb železne dobe in rimskih artefaktov vse do tolminskega kmečkega upora (1713) in do sodobnosti. Dan smo zaključili z vzponom na arheološko najdišče Tonovcov grad z 
ostanki treh poznoantičnih cerkva (nad dvema so zdaj znova zgradili poslopji) in z ostanki hiše malce niže.

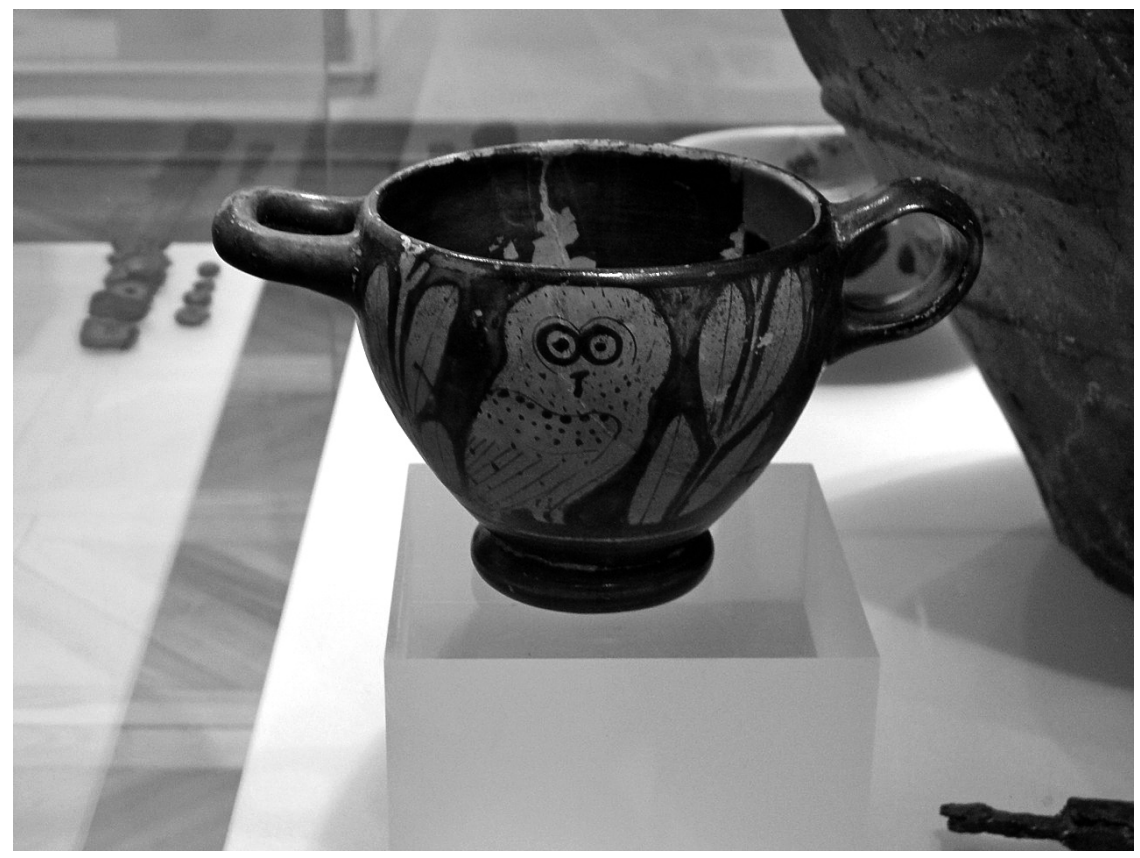

Na začetku kulturnozgodovinske poti je niša z repliko grškega skifosa iz 5. stol. pr. Kr., okrašenega s sovico med oljčnima vejicama, katerega original (na sliki) hrani Tolminski muzej. Posodico je našel Miha Mlinar v enem izmed grobov na Mostu, sovica pa je postala simbol poti Čez Most po modrost. (Slika: David Kovačič)

Nada Grošelj 